\title{
Pinjarra 1970: Shame and the Country Town
}

\section{Robyn Ferrell}

In 1970, I was a kid living in Pinjarra, a country town in Western Australia. There was a strange flatness to life, as lived in that town. The main street, interpreted by the Department of Main Roads photographs taken that year, was distinguished only by the make and model of each vehicle parked against the kerb. Images show the detail of the town to be unspectacular, prosaic to the point of banality, without ambition.

Was it the locale-low-lying river flats, sometimes becoming marsh? Or the flinty light? The extreme Western Australian sun, even in winter, screens out rich colours. Or something less tangible, like a fate that had befallen it, a curse on its aspiration, of which the town was all the same unaware? Or simply bad conscience from an unacknowledged crime? From whatever combination, Pinjarra took a perverse pride in the ordinary.

And yet, unbeknown to it, Pinjarra in 1970 lay on an extraordinary cusp. It lagged along a fault line between one order and another; or rather, it squatted at a precipice, over which its cherished values had already been dashed to pieces. In 1967, Aboriginal people were at last, by national referendum, counted in the Australian census. In 1969, Alcoa began to prepare the site in the hills behind Pinjarra for the open cut mining of the largest bauxite deposit so far discovered in the world.

The past met the future, and they didn't recognise each other.

I remember now the feelings of exclusion that were in that town an inescapable emotional reality. I notice now the contradictions that made it seem unremarkable at the time for 
Aboriginal men to lie drunk and ignored in the park outside the pub, for Aboriginal kids to slide into the playground and be driven off at 'playtime'. The kids from the old farming families never doubted that they were the first settlers in the area. But before European settlement, Pinjarra was called Bindjareb and had been a locus of the wandering lives of the several Murray tribes for generations without number.

The boys off the school bus greeted the Aboriginal kids with jeers, when they occasionally ventured to school as the law required them to. Maitland Howard was in our class. He came to school in school shorts but no shoes, and his feet looked like they never wore shoes. He wiped a perpetually running nose on an unravelling sleeve of an old school jumper, but he frequently had no shirt. I can see him stealing a drink at the taps in the playground, before running away from school again, before he could hear the other children warning each other which tap he had drunk from.

I was not myself at the top of the social scale at the local primary school. I wore glasses and I didn't have long, fair hair done up with ribbons. I used words of several syllables, like 'fascinating'. I didn't live on a farm - I was shamefully afraid of horses and cows. I was no athlete, and I did well at tests. At school in 1970, I learned that our history began in 1829 when the Swan River colony was founded by Governor Stirling, who had a highway named after him. I learned that 'the town of Pinjarra lies on the banks of the Murray River, about twelve miles inland of the inlet named for Thomas Peel, who held the original land grant in the area'. I copied this rigorously into my social studies project on 'The Region'.

My best friend and I used to keep to ourselves at lunchtime. In the shade of the pump house, we read English school stories to each other and transformed ourselves into girls in the Upper Fourth at Mallory Towers, where tea was taken, and snow fell in the winter term, and good marks were admired.

That ambivalence also coloured the first school social we ever attended, which was held that year in the dusty, little hall let by the Country Women's Association. There was a new English girl at school that term; her parents were among many colonials who surrendered their posts as administrators in Tanganika or Rhodesia, and made for Australia, in the wake of 
independence for British colonies there.

Her mother was perhaps more used to the social life of the British in Africa - parties, balls and Government Housethan the compulsory ordinariness of the Western Australian scene. She sent her daughter to the dance in her cut-down wedding dress, while we all wore hot pants, and squirmed for her shame. I still feel uneasy picturing her, sitting all night on the benches around the wall, the classic wallflower trapped in someone else's colonial past.

That year, the new civic centre was opened, and the Murray Music and Drama group was formed. I was recruited to the cast of The King and I because a mob of kids was needed to be the King's children.

I was affronted to be designated as a Siamese twin with Lynn Gledhill, a girl I didn't like but who was the same height. We wore harem pants made out of old curtain material, and stained our skin with brown, and dyed our hair black, in order to make the transformation. But we were concerned to discover that even the King's children in Siam apparently wore no shoes, and had to sit on their heels for stretches of time that put our feet to sleep.

As well as being the director, Mrs Meares played the role of Anna and swooped imperiously across the stage in a ball gown with a hoop in it. We were captivated. Mrs Meares was from one of the oldest families in the district and the premier of the state came to the opening night. What a tale of exotic delights and unrequited desire! The Murray Music and Drama production was imbued with the crushing nostalgia of a colonial love of England, even though the details of the plot carried all the ambivalence of the colonised.

The King and I was a double parable of colonialism, since, while a story of British influence in South-East Asia, it was in fact a product of the American imaginary, a Rodgers and Hammerstein musical transferred to the screen in 1956, starring Yul Brynner and Deborah Kerr.

The story was freely adapted from the true account of Anna Leonowens, an English widow who went to the court of Siam as governess to the King's many children in the 1860 . The account had been popularised in the 1940 s by 
a novel by Margaret Landon, and had already been made into a film before Gertrude Lawrence put it before Rodgers and Hammerstein. But it was surely the greatest of its many ironies that it should become a musical-and one of the most successful of their successful career.

When Hollywood had finished with it, the sexual tension between Anna and the King eclipsed the sometimes traumatic meeting of East and West that is documented in Mrs Leonowens' own memoir. The traditional tyranny of the absolute monarch clashed with the more subtle but ascendant tyranny of colonialism, and by inviting the English governess to court King Mokmut appeared to appreciate (better than Broadway?) that this clash was a necessary evil for which his children needed to be prepared.

The musical raised the questions of slavery and inequality in the stories of the slave girl Tuptim and the King's relation to Anna, but it did so as figments of an American imaginary, which sought clues in Uncle Tom's Cabin and the possibility of romance. Decidedly un-American (and incomprehensible) elements - such as the sexual order that created the harem, and the hierarchical power that promoted the violence of everyday life - were ignored. And especially, above all, what was ignored was the precarious position of the Victorian Englishwoman in such a setting, nights spent in fear of her life and days in heartbreaking labour on behalf of values such as justice and humanity, which had no translation in the context in which she worked.

The film and the musical marvel at the strength of Anna's character, but they do so with an assumption of triumph given by hindsight. Her strength must have been much more remarkable than that-when one reflects on her situation, one can only conclude that her persistence betrays an almost insane conviction of the principles of her imperial age, despite being faced daily with their repudiation. Her strength, which was also a kind of blindness, is an iconic expression of the British imperialism she stood for.

But the American candifying of her story, the jolly 'getting to know you' of the musical rendition, is an even truer expression of the American imperialism that colonised her 
colonialism, making something quite different from it. And so, in the funny unconscious fashion of things in Pinjarra, The King and I became the only possible testament to the events of 1970, and Mrs Meares the more-than-faithful repetition of the convictions of Anna Leonowens. When she whisked across the stage in the crinoline 'which was itself a character in the play', her own inhabiting of the role showed it to be a myth that was explaining, for other purposes, another colonial scene.

I didn't learn of the event known locally as 'the Battle of Pinjarra' at school, although I heard it mentioned. Details were sketchy, but it was said to have happened down at the river. Certain names - Stirling, Peel and 'the battle of Pinjarra' - the Murray River Aboriginal Association are now requesting be changed out of respect for the dead. They want it renamed the Pinjarra massacre, as a record of the violence visited on the tribal ancestors.

Pinjarra had been a 'frontline' of colonial settlement, because it offered the best farming land south of the Swan River colony itself. It was in 1834 that Governor Stirling, Thomas Peel and some military men (among them Captain Meares) ambushed a group of about seventy of the Murray River tribe on the banks of the river at Pinjarra. It was the time of the year when the tribe was known to gather for ceremonials in the area. That morning it seems many of the warriors of the tribe were over at another camp on Peel Inlet for male initiation ceremonies. The group who were left at the river were mostly the elderly, women and children. They were fired on as they tried to flee.

Official reports put the number shot at fifteen to twenty. Other eye-witness accounts, and those in the oral history of the Aboriginal people, put the number at conservatively twice that. The consequences of so many deaths were that many more of the tribe died in the subsequent year, of starvation, because the food taboos arising from various totems prohibited the food supply. Some of the settlers congratulated the governor for having put an end to 'the native threat'. It is true that land grants in the area were able to be taken up in the wake of the ambush and the area 'opened up', as historians say.

But why was the governor of the colony, newly formed only five years earlier, firing on unarmed people whom his colonial 
policy obliged him specifically to 'protect'? With hindsight, we might attribute the attack to the violence of colonisation, which despite its pious dressing as an attempt to extend the gift of civilisation to the savages, was, in fact, an act of conquest.

To the first colonists, the resistance provided by the Aboriginal tribes of the region had been an unwelcome surprise. While today the appropriation of the Aboriginal lands by a superior force may seem to have been a foregone conclusion of European 'settlement', it was the efficacy of the guerrilla tactics of the Aborigines in protecting their land that was more evident at the time. It produced the massacre as a heavy-handed response.

Some misconceptions - fatal for the Aboriginal peoplehad restrained the tribes from expelling the settlers right at the beginning, as they would have any group of invading Aborigines. The tribes are reported to have extended respect to the Europeans in the belief they were returned ancestors. They were also inclined to view the flour rations, which they were doled out by the Europeans, as a payment for the forced resumption of hunting lands for farming. But the Europeans, thinking it was charity, cut the ration when food in the colony became short.

The massacre was preceded, and justified at the time, by the killing of two soldiers in a raid made by the Aborigines on a mill at South Perth. What the Aborigines might have imagined was exercising their lien, the Europeans called theft, and murder. The homily that Governor Stirling claims to have delivered to the survivors of the massacre describes it as a 'punishment', and warns them that 'the white man never forgets murder'.

But of course he has, many times, in the tarnished history of European settlement. The 1998 report on the massacre pressed to have the site of the Pinjarra massacre declared a heritage site, not on the grounds that it was a unique event in Western Australian history, but on the grounds that events like it were shamefully common. What distinguishes this massacre from many other scenes of unwarranted violence by settlers that contradicted British official policy was the leading role played in it by so high a British official as the colony's 
governor, and the fact that, because of him, it was written down.

European settlement became colonial government in time. Western Australia grew prosperous on wheat and sheep, and on mineral finds such as gold and iron ore. Colonialism gave way to globalisation. Enormous deposits of bauxite were uncovered in the ranges around the town, and new settlers arrived, this time from Pittsburg, Pennsylvania, to build executive air-conditioned homes with Alcoa mining money.

The air-conditioning said it all. West Australians had lived whole lifetimes suffering the heat, but it had never occurred to people before 1970 to install air-conditioning. Climate control was beyond the town, and in fact was an ontological challenge to it.

The head executive's wife further shocked us by producing from the pantry chocolate dog biscuits for her poodle. No one had ever contemplated such indulgence of dogs before; it was unclear whether anyone had even kept a poodle in Pinjarra before this second wave of colonialism - there were only ever kelpies, cattle dogs and mongrels. No one had put down white carpet in their home before these people, either - these affectations were impressive, but we felt somehow slighted by them, too, and so we ridiculed them.

Mining interest in the area began in the 1950 shen a small Australian company called Western Mining, which was at that time mining gold in Kalgoorlie among other interests, discovered the extent of the bauxite deposits in the Darling Range. But the venture took off after the involvement of the American mining giant in 1961. In the four years from 1968 to 1971 , a total of $\$ 241$ million was spent on construction for the enterprise. By the early 1990s, Alcoa of Australia would produce nearly one sixth of the world's alumina. The biography of its success, a company history titled White Gold, was written by Geoffrey Blainey, who had an altogether more ambivalent claim to fame in Australian history circles as a latter-day advocate of 'white Australia' policies.

Western Mining, whose principals had developed the bauxite project from exploration, was unable to raise Australian finance to carry through the project of mining and refining the aluminium alone. This fact by itself explained 
the new colonialism that, in consequence of this opportunity and others, opened up Western Australia to American influence. The east coast, especially Sydney, had had contact with American cultural imperialism almost continuously since World War II, and admired many things American. But Western Australia had preserved a steadfast British identification that was offended by the frankness of the American sensibility.

In the small world of Pinjarra, the influx of American prosperity was resented in a way that may have taken the new settlers aback. But although myopic and bigoted, this resistance had some grasp of the economic reality it faced; despite the appearance of generosity, the American interests intended to take away more than they put in. The locals certainly recognised as familiar the class distinction of Alcoa's arrangements; they brought out their own executives to live in the new houses by the river while the ordinary work force were set up on an industrial reserve on the outskirts of the town. But, accustomed as the town was to class distinction, the locals spent as much time currying favour with the new overlords as they did in running them down. The opening up of mining saw merely a double entrenchment of colonialism-American on British - and reinforced the convictions of caste that structured the town.

The Aboriginal people were living, as they had been for decades, in 'native' reserves on the edge of the town, but by 1970 they were about to encounter postcolonialism, the beginning of the present. In 1972, responsibility for their affairs would be transferred from the domestic abuse of the state government to the 'international responsibility' of the federal.

Europeans believe the massacre 'finished off' the Murray River tribes, but the reserve still existed outside the town as an eyesore into the 1970s, for anyone who cared to look. As an elder has said: 'We didn't have the privilege to express our views until the 1970s.' And another descendant has said, in response to the comment that the battle has only recently been viewed as a massacre: 'I don't think they [the Ngunyar] had time to worry about things like the Massacre. They were too busy surviving from day to day.' 
The administration of Western Australian Aboriginal people had been a continuing shame. The massacre at Pinjarra provoked a kind of 'surrender' by the tribes, who sought a meeting with Governor Stirling following it, at which they reportedly pledged loyalty to the British Crown. But in the century that followed, the Crown hardly returned this loyalty, exposing the 'native' population to the dangers of dispossession, drink, disease and miscegenation.

The tribes suffered the forced removal of children, curfew and banishment from towns: 'During these years, it was not uncommon for Aboriginal people to be thrown into jail for answering back to a policeman, or if they were found on the streets after dark'. 'Native' reserves in Western Australia had no houses on them, no toilets and no running water until the 1960s. They were often located outside the town, next to the rubbish dump. The neglect on reserves, and the squalor, was not lessened by censorship-Europeans were not permitted on them without a permit, nor were photographs permitted to be taken. The councils opposed, in many cases, Aboriginal applications to build on land they owned within the town limits, and the improvement of living conditions was not given suitable funding by a succession of government administrations. But however the council might try to remove the contamination, of the townspeople by Aboriginal people, of the Aborigines by the town, our common shame demoralised both, and compromised the making of community.

The banality of any country town afternoon. Dragging home from school on the gravel; past the school oval which peters out in scrub; past the council depot where the graders lie asleep; the smell of tar; a little brick building without windows or any known use; the milk bar with its plastic flystrips slapping; the highway, along which the trucks thunder, anxious to be gone. Scuffing along the shoulder of the highway in the afternoon heat. The insult. Feeling left behind, by those trucks, feeling abandoned.

Eyes dropped, so as not to see the Aboriginal men lying dead drunk on the grass in front of the Premier Hotel, 150 metres and 150 years upstream from the massacre, which tragedy they echoed, only so quietly and self-effacingly that they weren't heard. Guilty and sinning, dragging down the 
main street eating a gluey pie from the bakery even though 'they made you fat' and it was 'unladylike' to eat in the street. Feeling awful, feeling the eyes of others judging. It made you walk funny ...

The only cure for this self-consciousness was speeding through the bush tracks on the bike, or riding down to the river, there to screw up courage and swing out over the water on the gazinta. Dropping into the slow, viscous river water, which was warm for the first two feet as though someone had pissed in it and freezing cold when you duck-dived. The water was completely opaque. Straggling to the bank, swimming shallowly in case you caught a snag, scrambling out before the leeches could get you. Sometimes we came upon the Aboriginal kids playing there, on a hot day. We didn't want to join them, and they didn't welcome us. We wandered disappointed up the bank, and back home to play under the sprinkler instead.

Today, Nyungar people are tracing their family back to the group at the massacre. And as part of making history they are emphasising other, more positive exchanges, with settler families - the bush medicine provided, the hardship settlers and Nyungars shared. Because exactly who and what was colonised? The despair of the ordinary colonial-camped on the beach with the flies for company in the first year of life in the colony, or clearing the jarrah trees from his land in the boiling sun before he could build, much less farm - was poignantly rediscovered by Western Australians in the 1970s, when they found an appetite for local and oral histories.

In the wake of contemporary calls to European Australia to apologise to Aboriginal Australians for the brutality of colonisation, including the Stolen Generations, I need to go back to the 'country town'. It is a form of community remote from my adult life, but one which I remember vividly, with my whole body, in everyday abjection and shame.

The country town, in its abjection of Indigenous people and the various others it regarded as outsiders, offered a concrete experience of shame, as the affect of the social. Shame is brought on by other people. More abstractly, shame is instituted by community to effect an indifference to others. 'Don't stare, it's rude.' 
Shame is a source of political community, in that it is the experience of binding and bonding between members of a community, in the ambivalent sense that these words suggest. They are bound by their feelings about themselves and the world. Shame describes and proscribes an affective community, before law, before strategy, scheme, plan, program and legislation - a spontaneous and unavoidable bond that comes about just in virtue of being in proximity. Shame calls you into its community, there to suffer under the same yoke as everyone else. 'We're all in the same boat.' The 'we' of this community is not an assumption of collective goals but a constraint on the individual, through which he must find his expression.

At its most technical, shame is described by the psychoanalyst Silvan Tomkins as that affect which is the experience of interrupted enjoyment or interest. It can name an experience in which we are momentarily halted in our enthusiastic greeting by the coolness of the visitor; it can name an experience in which we prevent ourselves from looking at someone, despite desiring to, because it would be 'rude'; it can name the experience of being rebuked for our present being, as in when we are told 'no need to cry'.

Recognition is the social act it interrupts, and recognition between people is subtle and pervasive. The flows of shame, and the threat of it, modulate our interactions with others through what Tomkins terms 'shame theories'. These are generalisations or summaries from past experience that each person uses to guide present response. The experiences of shame are intense in childhood, but gradually ease as we grow and invent these 'shame theories' to protect ourselves from experiencing the feeling itself.

Tomkins calls them theories because they explicitly work to predict and control the level of experience of uncomfortable feelings. But they are also theories in a more technical sense; that is, they are the products of reflection and are open to revision. Tomkins characterises shame as the most reflective of affects; conversely, contempt is the least reflective. Contempt betrays no self-evaluation at all and not a minute's self-reflection, whereas shame is the affect of reflection, the feeling that we have when we become aware of ourselves in 
the light of others. It is thereby the feeling of self-formation, and, seen in this light, a founding experience of oneself, and of social life.

This makes shame a wide-ranging affect - from the mildness of dropping eyes in modesty (where nevertheless there may even be some thrill in the possibility of seeing and being seen), to the raging humiliation of a defeat in front of others whose respect is cherished and whose negative judgement is made visible.

It is also, by its nature, the fundamental social affect, because it is the feeling of being in relation to others, and of being aware of it, whether that self is rewarded or repudiated in the eyes of others. Because of the mimetic nature of the human, we see ourselves in each others' eyes; but we would never become aware of ourselves as individual if not for the reflection set in motion by another's judgment, and the corresponding self-reflection of shame. Before this, one exists in an empathic continuum with the feelings of the other, assuming her feelings to be his and vice versa. This infant state, however, is hypothetical, even in the happiest and most loving childhood, disturbed by the inescapable intrusion of the feelings our own actions inspire in others.

Tomkins thus draws a straight line out of the intimacies of the familial bond to the socialisation of shame, without any heavy oedipal machinery: interruption of the flow of affect between the child and another is experienced as a jolt into selfreflection. The child's feelings are passionate and unguarded about the contingencies of a childish life, which are so often frustrating. Whether the parents' reactions to these feelings are themselves harsh with judgement ('Don't be a silly boy!') or whether they are empathic ('There there dear, did you get a fright?'), they have the effect of drawing to the child's attention his own feelings of self and his correlative separateness from others.

The country town is an exemplary affective community, in that the unavoidable nature of its calling to one is what engenders also the sense of defeat and abjection. It may seem odd to describe a town like Pinjarra as an affective community, while at the same time saying that it is known for the flatness of the affect it engenders. But boredom - which is the affect 
of flatness - is a powerful feeling, and a complicated one. Boredom is a complex in which anger, shame and fear are contained by a fierce effort of withdrawal of interest. Boredom is an affect founded on frustration, because there is nothingor nothing safe enough - in which to invest one's desire.

Pinjarra in 1970 was an experience of community from which the affect had been leached out, and had become lifeless and dull. This belied the terrific strength of the restraining of affect, which gave rise to its flatness, and which was embedded in the denial: Nothing ever happens here.

For the truth was far different; indeed, the founding deceit of this flatness, whose surface was seemingly so baked-on and enamelled, was the suppressed horror: Something once happened here.

The Pinjarra massacre stands as a literal event of colonialism, one which forced denial on all of its subjects, European and Indigenous, from the governor down, and bound them together in their shame. What else was colonialism but a kind of cheating and of theft, covered up with lies - the cheating that took what it wanted with force, this theft of land and life from the Indigenous people but also of hope and dreams and labour from the settlers, and the lies that were told about Empire and common law and civilisation to deny it?

But deep down, that is, unconsciously, it didn't fool people, and so it produced the impossibility of community, the blocking of that affective bond which could take pride in country, or feel passion for a culture, or feel real communion with fellows, or feel anything more than shame for membership of it. Under the weight of shame, the colony began the habit of living elsewhere from its inception. First it was 'home', and the 'mother country', then by degrees it became the city (Perth), or the 'Eastern states', Pittsburgh and Hollywood and New York-all places we went in our minds where things were paradoxically more real to us. We knew their histories, we knew their current events; we valued their styles and opinions far above our own.

This was a failure to inhabit built on the original deceit which founded the colony, and which makes Pinjarra representative of a general colonial dejection. Postcolonially this is not cured, because there are still centres and margins, and especially there are centres and margins, in the strange 
parochialism of the global village.

Pinjarra residents tried in self-conscious ways to invent at the surface what was prohibited deep down - this was the motivation of the Murray Music Group. But the prohibition was also why it was a group desiring to perform musicals about colonial-sexual nostalgia and misgiving, like The King and I, rather than a group writing the history of the place, called 'Murray' in one language, but which had known many others. The latter group had to wait until 1998 to see their report published. And still the librarian kept it under the desk in the library, for fear it was salacious and might ignite other curiosity, perhaps. 'I don't know if you're allowed to see that', she said to me when I inquired. 'But it's a public document!' I exclaimed, amazed at the tenacity of the shame.

Thinking about shame Tomkins' way explains how the intimacy of feelings, especially childhood feelings, might be integral to the political field and indeed conjure it as experience in individual lives. In Pinjarra, the parade of oneself walking down the main street was a scene set by shame and lived in that way, if one was at all given to reflection. For some, the experience of shame would have been more intensely supported by the contempt of others. But even a European schoolgirl felt it powerfully containing, and at the same time, constraining her.

Canberra 1975. Many Australians cried 'Shame Fraser Shame' in outrage at the dismissal of a progressive government through an instrument of colonial anachronism. They were calling this affect political then, but today Fraser's then deputy and our current prime minister, John Howard, refuses to apologise for the shame of Aboriginal dispossession on the grounds that it is a matter of conscience, not of law. Yet Pinjarra shows that conscience is law. Conscience is the affect of that which law is the principle.

What shames Australians today about the Prime Minister refusing this shame is its shamelessness. Indigenous, refugee, migrant and all, thrown back against the community of shame from which 'multiculturalism' for all its faults, attempted to release us.

Ironically, Fraser is today a vocal critic of the shame of racism and the treatment of Indigenous people. In his work 
against apartheid and now in his criticisms, he puts the Howard government to shame. But Howard still lives in the Pinjarra of 1970, shoring up the banality of middle Australia by counselling denial and withdrawing into boredom. The possibility of reconciliation between Aboriginal and European Australians is predicated on being 'sorry' and saying it - and if this sounds like the logic of childhood, it is because abjection infantilises the whole group. Pinjarra 1970 is a case study, in order to put the hard question: How today can this 'sorry' be addressed?

\section{Reflection}

Writing 'Pinjarra 1970' brought together two threads that I continue to follow in the decade since its publication: working in creative nonfiction, and researching Indigenous issues. I was able to explore both at greater length in Sacred Exchanges: Images in Global Context (Columbia University Press, 2012). In that book, I wrote about the question of how Aboriginal acrylic painting captured a global moment because of its abstract 'look'. The book looked at the paradox of painting that is both so old-the oldest continuing tradition of sacred art-and so new-a vivacious visuality apparently extending the abstract expressionist brief. I found it stirring to write about the surface effects of the work alongside the deeper conflicts of the context, including the unjust conditions in which Aboriginal artists live and the fickle transformations of the culture market.

I shared an ARC grant to research and write Sacred Exchanges, which made possible fieldwork both to the desert art centres in the Northern Territory and the Kimberley and to the international museums like Musee du quai Branly in Paris. I recently recorded the experience of scholarship in this troubled area in a creative nonfiction style as in 'Pinjarra 1970' in a piece, 'Whitefella Worship', published in Text (Special Issue 17, 2013).

The great strength of creative nonfiction for me has always been its capacity to mobilise affect as part of its discursive frame. This still strikes me as particularly necessary in subjects like Indigenous Studies, where feelings are a key part of its material. In 'Whitefella Worship', the ironies of the Aboriginal art market, and the place of white women scholars like myself in its research, seemed to impel me to this kind of writing, where I could register 
both the beauty of the work and the pain of ambivalence about the circumstances in which it comes about.

Although a great deal has happened to challenge white complacency since I began work on 'Pinjarra 1970', the contradictions still seem immense. And with greater exposure has come new challenges; in particular, for those writing Indigenous studies to tackle the questions of the 'power to say' - who has it and who is silenced, including within the hegemony of the increasingly corporate university. I want to congratulate the journal, and in particular the energetic editorship of Katrina Schlunke, for opening a space for creative nonfiction and more generally for 'new writing in the humanities'. Without this forum, I would have struggled to give shape to these ambitions for writing about culture in a way that brings affect onto the same page as effect.

\section{References}

Jennifer Biddle, 'Shame', Australian Feminist Studies, vol. 12, no. 26, 1997, pp. 227-40.

Geoffrey Blainey, White Gold: The Story of Alcoa of Australia, Allen \& Unwin, Sydney, 1997.

Paul Hasluck, Black Australians: A Survey of Native Policy in Western Australia, 1829-1897, 2nd edn, Melbourne University Press, Melbourne, 1970.

Anna Leonowens, The English Governess at the Siamese Court, Barker, London, 1954 (1870).

The Murray River Aboriginal Association, Report of the Pinjarra Massacre, 1998.

Frederick Nolan, The Sound of Their Music: The Story of Rodgers and Hammerstein, Dent, London, 1978.

Silvan Tomkins, 'Shame-Humiliation and Contempt-Disgust', in Eve Sedgwick and Adam Frank (eds), Shame and Its Sisters: A Silvan Tomkins Reader, Duke University Press, Durham, 1975.

West Australian Department of Native Affairs, annual reports 1970-1974. 